\title{
An evaluation of extraction techniques for arsenic in staple diets (fish and rice) utilising both classical and enzymatic extraction methods
}

Sadee, BA

http://hdl.handle.net/10026.1/4837

10.1080/19440049.2015.1132479

FOOD ADDITIVES AND CONTAMINANTS PART A-CHEMISTRY ANALYSIS CONTROL EXPOSURE \& RISK ASSESSMENT

All content in PEARL is protected by copyright law. Author manuscripts are made available in accordance with publisher policies. Please cite only the published version using the details provided on the item record or document. In the absence of an open licence (e.g. Creative Commons), permissions for further reuse of content should be sought from the publisher or author. 
Disclaimer: This is a pre-publication version. Readers are recommended to consult the full published version for accuracy and citation. Published in Food Additives and Contaminants:

Pt A, 33, 433-441 (2015), DOI:10.1080/19440049.2015.1132479

\title{
An evaluation of extraction techniques for arsenic in staple diets
}

\section{(fish and rice) utilising both classical and enzymatic extraction}

\section{methods.}

\author{
Bashdar A. Sadee, Mike E. Foulkes and Steve J. Hill
}

School of Geography, Earth and Environmental Sciences, University of Plymouth, Plymouth

PL4 8AA, UK

NOTICE: this is the author's version of a work that was accepted for publication in Food additives and Contaminants: Pt A. Changes resulting from the publishing process, such as peer review, editing, corrections, structural formatting, and other quality control mechanisms may not be reflected in this document. Changes may have been made to this work since it was submitted for publication. A definitive version was subsequently published in Food Additives and Contaminants: Pt A, [VOL 33, (DATE 11 February 2016)] DOI:10.1080/19440049.2015.1132479

\begin{abstract}
Enzymatic extraction methods were evaluated with classical extraction approaches for arsenic in food. The extraction efficiency for total arsenic was determined by analysing the CRM materials DORM-3 fish protein, NIES rice flour and GBW10015 spinach. These were compared with total arsenic concentration determined using microwave assisted acid digestion and ICP-MS. The total arsenic concentrations in the CRM materials were in good agreements with the certified values.

Enzymatic hydrolysis using trypsin has been successfully employed to extract arsenic species in DORM-3 and fish samples. Whilst this method of hydrolysing the proteins worked well for the fish samples, an alternative approach was required to facilitate the cellulose in plant
\end{abstract}


materials. However, enzymatic extraction using cellulase was found to give unsatisfactory results for both the NIES and GBW10015 CRM materials. Dilute nitric acid (1\% $\left.\mathrm{HNO}_{3}\right)$ was found to give a more efficient extraction for arsenic species in the same CRM materials and rice samples. The study was extended to evaluate a range of real samples. Total arsenic concentrations in 13 different types of fish tissue were determined following microwave assisted acid digestion using nitric acid/hydrogen peroxide, followed by measurement using HPLC-ICP-MS for speciation analysis. The results obtained for fish were in the range of 3.53-98.80 $\mu \mathrm{g} \mathrm{g}^{-1}$ As (dry weight). Similarly, the results of 17 rice samples were in the range of $0.054-0.823 \mu \mathrm{g} \mathrm{g}^{-1}$. This study demonstrates the importance of selecting an appropriate extraction technique for the quantitative measurement of arsenic species in food.

Keywords: arsenic species, extraction efficiency, enzyme, CRM and ICP-MS

\section{Introduction}

Arsenic is a ubiquitous element which exists at low concentrations in rock, soil and natural ground water. Although arsenic has the reputation of being a toxic element, it also well established that its toxicity critically depends on the chemical form in which it exists and that the inorganic species, arsenite (As ${ }^{\mathrm{III}}$ ) and arsenate $\left(\mathrm{As}^{\mathrm{V}}\right)$ are classified as more toxic than organoarsenic compounds (Sanz et al., 2005). In natural ground water arsenic is mainly present as inorganic species arsenite (As ${ }^{\mathrm{III}}$ ) and arsenate (As ${ }^{\mathrm{V}}$ ) (Milstein et al., 2003). To date, over fifty arsenic species have been identified in marine organisms (Francesconi, 2010). Organic arsenic forms such as arsenobetaine and different arsenosugars are the most common forms in marine products, whereas in food of terrestrial origin, inorganic arsenic and organic arsenic (methylarsonate (MMA) and dimethylarsinate (DMA) are the predominant forms (Sadee et al., 2015). Drinking water is the most common route for exposure to arsenic (Gallagher et al., 1999; Heitkemper et al., 2001) and contaminated water and soil are the 
main sources of arsenic in the food chain (Francesconi, 2005). However, the total level of arsenic in food staples can vary by a factor of 1000 (EFSA, 2009; Pétursdóttir et al., 2014).

The extraction technique of choice for a particular application reflects both the matrix and the species to be determined. A mild and efficient extraction technique is required for the accurate determination of arsenic species in plants using HPLC-ICP-MS. Trypsin has been used for extracting arsenic species from fish and crustacean with an extraction efficiency of between 82-102\% (Rattanachongkiat et al., 2004). Protease and $\alpha$-amylase have been used with an ultra-sonic probe to extract arsenic species from rice, fish and chicken with the recovery of 98.4-109.3\% (Sanz et al., 2005) . Reyes et al. (2009) used a microwave-assisted enzymatic extraction using a pronase E/lipase mixture to extract arsenic species from shark with extraction efficiency of $101 \pm 0.01 \%$ and from commercial fish (marlin) $63 \pm 1 \%$. Pepsin has been used as an extractant agent with pressurized liquid extraction to speciate arsenic forms in a range of different fish with an extraction efficiency of 95 to $103 \%$. Enzymatic extractions have also been used to extract arsenic species from apples. In this example $\alpha$-amylase was used with extraction efficiency in the range of $79-117 \%$ (Caruso et al., 2001). $\alpha$-amylase was also used to extract arsenic from rice samples to hydrolyse the starch prior to extraction when using $50 \%$ methanol. Here the arsenic was extracted from rice sample with an extraction efficiency of only $59 \%$ but when applied to a rice flour SRM (SRM1568a) this increased to $97 \%$ (Heitkemper et al., 2001).Thus, the extraction yields are strongly depending on the plant composition and the extraction method used, potentially leading to irreproducible results.

Fish and rice samples were selected for this study because they represent important food staples in the diet of human humans. Fish has been identified as an important contributor in human exposure to arsenic, although the arsenic levels are known to differ between species. For this reason a range of common deible species have been selected for this study. Similarly according to Zayala et al. (2008) the "global normal" range for arsenic in rice grain is 0.08 to 
$0.2 \mu \mathrm{g} \mathrm{g}^{-1}$, however, the majority of Asian rice has arsenic levels less than $0.098 \mu \mathrm{g} \mathrm{g}^{-1}$, whilst in contrast, rice from the USA and EU has a reputation for high arsenic levels. Again, a range of samples of different geographical origin were selected for this exercise.

The overall aim of this study was to characterise the extraction efficiency of enzymatic and classical extracting agents for the determination of arsenic in the staple food samples identified above.

\section{Experimental}

\subsection{Chemicals}

Analytical reagent grade chemicals and Milli-Q water $(18 \mathrm{M} \Omega \mathrm{cm})$ were used throughout unless otherwise stated. Total As standards were prepared from the high purity stock solution $100 \mu \mathrm{g} \mathrm{ml}^{-1}$ in $5 \% \mathrm{HNO}_{3}$ (CPI international, USA). Arsenic oxide (As ${ }^{\mathrm{III}}$ ) was purchased from Aldrich (Milwaukee, USA). The DMA and arsenobetaine (AsB) were purchased from Sigma (Gillingham, Dorset, UK), and MMA was purchased Chem Service (West Chester, Pennsylvania, USA). $\mathrm{Na}_{2} \mathrm{HAsO}_{4} \cdot 7 \mathrm{H}_{2} \mathrm{O}$ (As ${ }^{\mathrm{v}}$ ), Cs, In, Ir and ammonium dihydrogen orthophosphate Analar standards were obtained from VWR International (MERCK), Lutterworth, Leicestershire, UK). Hydrogen peroxide 37\% and nitric acid 70\% (Merck, Poole, Dorset, UK) were used. GBW10015 spinach certified reference material (Institute of Geophysical and Geochemical Exploration, Langfang, China) was purchased from LGC standards (Middlesex, UK).Trypsin (from bovine pancreas: 11800 units $\mathrm{mg}^{-1}$ ) was purchased from Sigma (Sigma, Gillingham, Dorset, UK). The CRM DORM 3 (fish protein), was obtained from National Research Council, Ottawa, Canada.

\subsection{Instrumentation}

ICP-MS analysis was performed using an X Series 2 instrument (Thermo Scientific, Hemel Hempstead, UK). The operating conditions employed are described in Table 1. Collision cell 
technology was used to eliminate the possible argon oxide interference. Indium and iridium were used as internal standards for all samples at a final concentration of $10 \mu \mathrm{g}^{-1}$. The mass spectrometer was set to sample As ion intensities (peak jumping option) at mass. The signal intensity was sampled at m/z $115\left(115 \mathrm{In}^{+}\right)$and m/z $193\left(193 \mathrm{Ir}^{+}\right)$for internal standardization.

The HPLC instrumentation operating conditions are presented in Table 1. Chromatographic separations (isocratic elution) were carried out using a Waters 6000A chromatographic pump (Waters, Milford, MA, USA) with a 250 x $4.6 \mathrm{~mm}$ column packed with $10 \mu \mathrm{m}$ particle sizes Hamilton PRP-X100 anion exchange resin. A 50x4.6 mm guard column packed with the same material was used to protect the column. A Rheodyne 7152 injection valve (Rheodyne, Cotati, CA, USA) employing a six-way injection port was used. The interfacing between HPLC and ICP-MS was carried out using Teflon capillary tubing $(0.5 \mathrm{~mm}$ i.d $)$ which connected the column outlet directly with the inlet to the nebulizer. An Oakton $\mathrm{pH}$ meter (Eutech Instruments, Singapore) was used to take $\mathrm{pH}$ readings. The ICP-MS was set to timeresolved data acquisition. Data for arsenic m/z $75\left({ }^{75} \mathrm{As}\right)$ for total arsenic were recorded using the peak jumping acquisition and displayed as mass-intensity-time plots. The concentration of each arsenic species was calculated using peak area and compared with known concentration standard solutions.

\subsection{Sample preparation}

The different fish samples (ling, gurnard, grey mullet, pollock, dover sole, john dory, megrim, flounder, dab, sand sole, brill, lemon sole, halibut) were purchased from Plymouth Fish Market and then returned as quickly as possible to the laboratory. The bones, scales, heads and tails were separated from the tissues and washed with Milli Q water. All samples were then frozen at $-40{ }^{\circ} \mathrm{C}$ for $12 \mathrm{hrs}$ in a freezer and then place in a freeze drier for $48 \mathrm{hrs}$ at -40 
${ }^{\circ} \mathrm{C}$. The freeze-dried samples were then ground using an agate pestle and mortar to a fine powder and then sieved using a nylon sieve $250 \mu \mathrm{m}$. The samples were then stored in brown bottles and placed in a desiccator in order to avoid exposure to light and moisture until required for analysis.

A total of 17 polished rice samples were analysed. The rice samples were purchased from supermarkets in Kurdistan region-Iraq, Turkey and UK. Details of the rice samples with country of origin are listed in Table 2. All rice samples were freeze-dried, ground and sieved, and the $180 \mu \mathrm{m}$ fraction collected. Certified reference materials DORM-3 (fish protein), GBW10015 (spinach) and NIES (unpolished rice flour with high Cd level) were dried by placing them in an oven overnight at $105^{\circ} \mathrm{C}$, and then processed in the same way.

\subsection{Total arsenic determination}

Total arsenic in biological and food samples may be determined successfully using the combination of microwave digestion and ICP-MS (Nam et al., 2010; Nardi et al., 2009). A Mars Xpress microwave lab station (CEM, USA) with $100 \mathrm{ml}$ closed Teflon vessels with Teflon covers was used for the acid digestion of samples. Freeze dried samples $(0.25 \mathrm{~g})$ were weighted out in triplicate and placed into separate Teflon reaction vessels. $5 \mathrm{ml} \mathrm{HNO}_{3}(70 \%)$ and $2 \mathrm{ml} \mathrm{H}_{2} \mathrm{O}_{2}(30 \%)$ was then added and the vessels which were subsequently sealed. All samples were digested for $43 \mathrm{~min}$ at $1600 \mathrm{~W}$. In the first step of the digestion, the temperature was increased up to $160{ }^{\circ} \mathrm{C}$ in $15 \mathrm{~min}$ and then held at this temperature for a further $5 \mathrm{~min}$. In the second step of the digestion the temperature was increased from 160 to $200{ }^{\circ} \mathrm{C}$ in $8 \mathrm{~min}$ and then held at this temperature for a further $15 \mathrm{~min}$. After digestion the Teflon reaction vessels were allowed to stand at the room temperature until cool. Once the digestion was completed the samples were transferred quantitatively into volumetric flasks

and made up to volume with $2 \%(\mathrm{v} / \mathrm{v}) \mathrm{HNO}_{3}$, prepared with Milli Q water. The samples and 
standards were spiked with the internal standards (In and Ir) to give the final concentration of $10 \mu \mathrm{g} \mathrm{l}^{-1}$.

\subsection{Extraction procedures for the speciation of arsenic in solid sample}

\subsubsection{Procedure 1}

It is well-documented that trypsin can degrade protein and transform protein to its simpler components such as peptides and amino acids. The extraction procedure used here is based on the work of Rattanachongkiat et al (2004). This method breaks down dietary protein molecules to their component peptides and amino acids. Trypsin works effectively in a slightly alkaline environment, approximately $\mathrm{pH} 8$ at $37{ }^{\circ} \mathrm{C}$ (Branch et al., 1994). The arsenical species in the fish samples and CRM DORM-3 were extracted using trypsin enzyme in $0.1 \mathrm{~mol} \mathrm{l}^{-1} \mathrm{NH}_{4} \mathrm{HCO}_{3}$. A $0.25 \mathrm{~g}$ of freeze-dried sample and $0.1 \mathrm{~g}$ trypsin were accurately weighted into a potter homogeniser and $0.1 \mathrm{~mol} \mathrm{l}^{-1} \mathrm{NH}_{4} \mathrm{HCO}_{3}(10 \mathrm{ml})$ were added and homogenize with the sample then transfer to a plastic centrifuge tube. Another $10 \mathrm{ml}$ of 0.1 mol $1^{-1} \mathrm{NH}_{4} \mathrm{HCO}_{3}$ was added to rinse the homogenizing tube prior to transferring to the same centrifuge tube. The tubes were left in a shaking water bath at $37{ }^{\circ} \mathrm{C}$ for $12 \mathrm{hrs}$ and then centrifuged at $4000 \mathrm{rpm}$ for $20 \mathrm{~min}$. The extract was quantitatively transferred into a $25 \mathrm{ml}$ volumetric flask and spiked with Cs internal standard solution to give final concentration of $10 \mu \mathrm{g} \mathrm{ml}^{-1}$. Finally, the samples were diluted to volume with $0.1 \mathrm{~mol}^{-1} \mathrm{NH}_{4} \mathrm{HCO}_{3}$. The total As in the residual solid were measured using ICP-MS after extraction of the total As using microwave assisted-acid digestion. The extract was kept in darkness at $4.0^{\circ} \mathrm{C}$ for no longer than 1 week.

\subsubsection{Procedure 2}

An alternative method is to use cellulase to break down the cell wall. Cellulase works effectively in a slightly acidic environment, approximately pH 5 at $37^{\circ} \mathrm{C}$. Arsenical species 
in the selected CRMs (GBW10015 spinach and NIES rice flour) were extracted using cellulase enzyme in $0.1 \mathrm{M} \mathrm{CH}_{3} \mathrm{COONH}_{4}$. A $0.5 \mathrm{~g}$ sample and 0.5 cellulase enzyme were directly weighed into a potter homogenizer, $10 \mathrm{ml}$ of $0.1 \mathrm{M} \mathrm{CH}_{3} \mathrm{COONH}_{4}(\mathrm{pH} 5)$ was added. After mixing they were transferred into a centrifuge tube. Another $10 \mathrm{ml}$ of $0.1 \mathrm{M}$ $\mathrm{CH}_{3} \mathrm{COONH}_{4}(\mathrm{pH} 5)$ was added to rinse the homogenizing tube then transferred to the same centrifuge tube. The centrifuge tubes were capped and left in a shaking water bath at $37{ }^{\circ} \mathrm{C}$ for $12 \mathrm{hrs}$ prior to the samples being centrifuged at $4000 \mathrm{rpm}$ for $20 \mathrm{~min}$. The extract was quantitatively transferred into a volumetric flask $(25 \mathrm{ml})$ and spiked with In internal standard solution to give final concentration of $10 \mu \mathrm{g} \mathrm{ml}^{-1}$. The samples were diluted to volume with $0.1 \mathrm{M} \mathrm{CH}_{3} \mathrm{COONH}_{4}$. Again the extract was stored in darkness at $4.0^{\circ} \mathrm{C}$ for up to 1 week.

\subsubsection{Procedure 3}

This method is adopted from the work of Sun et al (2009). A $0.50 \mathrm{~g}$ sample was accurately weighted out into a $50 \mathrm{ml}$ polypropylene digest tube and $25 \mathrm{ml}$ of $1 \%$ of nitric acid was added and left overnight. Samples were then extracted using a microwave oven. In the first step of the extraction, the temperature was increased up to $55^{\circ} \mathrm{C}$ over 5 min and then held at this temperature for a further $10 \mathrm{~min}$. In the second step of the extraction the temperature was increased from $55{ }^{\circ} \mathrm{C}$ to $75{ }^{\circ} \mathrm{C}$ over 5 mins and then held for a further $10 \mathrm{~min}$. Finally, the temperature was raised up to $95{ }^{\circ} \mathrm{C}$ and held at this temperature for $30 \mathrm{~min}$. Samples were then cooled to room temperature and centrifuged at $3000 \mathrm{rpm}$ for half an hour. The supernatant was filtered through a $0.45 \mu \mathrm{m}$ filter (Millipore) and kept at $4{ }^{\circ} \mathrm{C}$ until analysis.

\section{Results and discussion}

\subsection{Figures of merit}

The limits of detection for AsB, As ${ }^{\text {III }}$, As ${ }^{\mathrm{V}}$, MMA and DMA using the 3 procedures are shown in Table 3. Detection limits were calculated as three times standard deviation of 
sample blank (mean of six times the background signal blank of the method) using the conditions in Table 1.

\subsection{Validation of analytical method}

To ensure quality insurance, a method blank was performed with each extraction procedure. Internal standardization with caesium, indium and iridium $\left(10 \mu \mathrm{g} \mathrm{l}^{-1}\right)$ was used to correct for instrument drift. The possible interference of ${ }^{40} \mathrm{Ar}{ }^{35} \mathrm{Cl}$ at $\mathrm{m} / \mathrm{z} 75$ was removed using a collision cell. The extraction efficiencies of each method was calculated by comparing the total arsenic concentration in the extract with the total arsenic concentration in the CRMs following a full microwave assisted acid digestion.

The analytical method for the determination of arsenic in both fish and rice samples was validated in this study by using appropriate certified reference materials i.e. DORM-3 fish protein, NIES rice flour (unpolished high level Cd) and GBW10015 spinach. The results of analysis of all three of CRM materials using microwave assisted acid digestion were in good agreement with their certified values. The recoveries were $101 \%, 104 \%$ and $108 \%$ for DORM-3, NIES and GBW10015, respectively. The validation parameters for the analytical procedures are presented in Table 4.

\subsection{Evaluation of enzymatic and classical methods}

\subsubsection{Fish samples}

Classical extraction methods using water (Wahlen et al., 2004), a mixture of water/methanol (Nam et al., 2010) or methanol/water followed by extraction of arsenic species from the residue with 2\% nitric acid (Whaley-Martin et al., 2013) have been used to extract arsenic species from marine species with variable extraction efficiencies. Water was used to extract 
arsenobetaine (AsB), arsenocholine (AsC), As ${ }^{\mathrm{III}}$, DMA, MMA, As ${ }^{\mathrm{V}}$ from lobster tissue and TORT-2 with a total extraction efficiency for arsenic of between $67.6-81.3 \%$ (Brisbin \& Caruso, 2002). Li et al. (2003) used methanol water to extract arsenical species in fish and shellfish with an extraction efficiency of between 61-91\%, while Gomez-Ariza el al (2000) achieved extraction efficiencies 76-96 \% for arsenic species in seafood using a methanol extraction and 91-95\% using a water-methanol extraction agent.

The values obtained for total arsenic in fish in this study using procedure 1 (described previously) and HPLC-ICP-MS are presented in Table 5. Arsenic species in food of (ling marine origin are often found with relatively high concentrations. The fish tissues under investigation, gurnard, grey mullet, pollock, john dory, dover sole, lemon sole, sand sole, brill, dabs, megrim, halibut and flounders) have a total arsenic content between 3.53 to 98.80 $\mu \mathrm{g} \mathrm{As} \mathrm{g}^{-1}$, on dry weight basis. The highest concentration of arsenic was found in halibut $\left(98.8 \mu \mathrm{g} \mathrm{As}^{-1}\right)$ while the lowest value was found in grey mullet (3.52 $\left.\mu \mathrm{g} \mathrm{As} \mathrm{g}^{-1}\right)$. These values are in line with previous studies (Francesconi, 2010).

The use of enzymes as an extraction agent for arsenic species may offer some advantage due to the selective hydrolysis of the major components within the cell. Thus, the mass of material could be decreased significantly, requiring less sample dilution and offering the ability to analyse arsenic species which are not extracted with conventional techniques (water or water/methanol) (Mattusch et al., 2006). Trypsin an enzyme which hydrolyses proteins, was therefore selected to extract arsenic species found in the tissues of various fish, working well for both fish samples and reference material DORM-3. Figure 1 demonstrates the elution pattern of the four arsenic species under investigation (As ${ }^{\mathrm{III}}$ is not detected in the fish samples) using the conditions derived experimentally using the Hamilton PRP X100 column. Baseline separation was achieved successfully and the analysis complete in 1000 seconds 
using the chromatographic conditions given in Table 1. A chromatogram obtained from the sand sole sample using anionic-exchange HPLC-ICP-MS is shown in Figure 2.

As reported widely in the literature, AsB was the most widespread and abundant of the organoarsenic compounds found in the fish samples in this study. The values ranged between 3.41 to $97.74 \mu \mathrm{g} \mathrm{g}^{-1}$, dry weight. The values for DMA varied according to the species of fish concerned with average concentrations between 0.1 to $0.46 \mu \mathrm{g} \mathrm{g}^{-1}$ for dover sole, john dory, grey mullet, flounder and lemon sole. Other species of fish gave values below the detection limit $\left(0.021 \mu \mathrm{g} \mathrm{g}^{-1}\right)$. As ${ }^{\mathrm{V}}$ was found in the range of 0.19 to $1.09 \mu \mathrm{g} \mathrm{g}^{-1}$ except John dory which was below the limit of detection $\left(0.027 \mu \mathrm{g} \mathrm{g}^{-1}\right)$. Nevertheless, MMA was found at trace levels in these fish with values were between 0.18 and $0.61 \mu \mathrm{g} \mathrm{g}^{-1}$. John dory was again an exception being below the limit of detection $\left(0.034 \mu \mathrm{g} \mathrm{g}^{-1}\right)$. Matrix matching was performed on extracts of grey mullet and lemon sole using trypsin, and as a consequence the extraction efficiency was improved for both fish samples. The flatfish examined in this study i.e. Dover sole, megrim, flounder, dabs, sand sole, brill, lemon sole and halibut were found to contain the highest level of As, the exception being John dory as noted above which contained a relatively low concentration of arsenic. These fish are carnivorous bottom feeders and are highly carnivorous feeding on the bivalves and molluscs which filter feed on the sea bed.

In terms of inorganic As, generally flatfish such as dover sole, John dory, megrim, flounder, dab, sand sole, brill, lemon sole and halibut contain higher inorganic As with values between 0.19 and $1.09 \mu \mathrm{g} \mathrm{g}^{-1}$ being recorded. Literature values for uncontaminated area suggest most samples fall within the range of 0.02-12.20\% of total As (Suñer et al., 1999), thus the values of inorganic As obtained in this study were comparable to those found by other authors. 
To maintain quality control DORM-3 was used as a certified reference material. The laboratory results for the fish material were in good agreement with the certificate value for total As using microwave-assisted acid digestion and enzymolysis (trypsin).

\subsubsection{Rice samples}

The total arsenic was measured (using the conditions presented in section 2.4) in NIES rice flour, GBW10015 spinach and rice samples collected from different geographical origin using microwave assisted acid digestion followed by ICP-MS. The results obtained for total arsenic in both CRMs and rice samples are presented in Table 6.

Enzymatic and chemical extraction methods (procedure 2 and 3) have also been performed to extract arsenic species in crop based CRM materials (NIES and GBW10015). Although enzymatic extraction with trypsin was used to extracted arsenic species in fish samples effectively utilising its action in hydrolysing proteins, it is not suited for plant material. Cellulase, a group of enzymes which act together to hydrolyse cellulose is better suited for this purpose.

Two further extraction methods (procedure 2 and 3) were therefore employed to extract arsenic species from both vegetable based CRM materials (NIES and GBW10015). Procedure 2 involves enzymatic extraction using cellulase. The efficiency of the enzymatic procedure for the extraction of arsenic species was compared with a traditional $1 \% \mathrm{HNO}_{3}$ extraction procedure (procedure 3) for both NIES and GBW10015. In this study anionic exchange chromatography and using $\mathrm{NH}_{4} \mathrm{H}_{2} \mathrm{PO}_{4}$ as mobile phase were employed for the separation of four arsenic species (As ${ }^{\mathrm{III}}$, DMA, MMA and As ${ }^{\mathrm{V}}$ ) in both rice and CRM materials. Using the chromatographic conditions in Table 1 provided good resolution of As III, DMA, MMA and As ${ }^{\mathrm{V}}$ (Figure 3). The results obtained for the rice sample and CRM materials are shown in Table 6 . The evaluated procedures were based on the comparison of 
the total arsenic obtained using extraction agent with total arsenic obtained using microwave assisted acid digestion. Procedure 2 demonstrated that the extraction efficiency for arsenic using cellulase as extraction agent was highly variable for both NIES and GBW10015 materials. The extraction efficiency using cellulase as an extractant was $163 \%$ and $119 \%$ for NIES and GBW10015, respectively. In addition, cellulase was not able to extract all of the arsenic from both CRM materials, with some arsenic species being left in the residue. The total arsenic in the residue was found to be 0.013 and $0.032 \mu \mathrm{g} \mathrm{g}^{-1}$ for NIES and GBW10015, respectively. In addition, cellulase showed a relatively poor mass balance for the sum of species within both the extracts and CRM materials using microwave assisted acid digestion. One of the factors that contributes to both the poor mass balance and the poor recovering when using cellulase is the variable arsenic content of the enzyme itself. Our studies gave a sample procedural blank of $0.046 \pm 0.003 \mu \mathrm{g} \mathrm{g}^{-1}$ As in the enzyme, which is in agreement with the work of Sanz et al (2005), Cuderman et al (2009) and Dufailly et al (2011). Cellulase is therefore not an appropriate extraction agent for the extraction of arsenic species in the selected CRM materials and rice samples. Recently, low concentration nitric acid (1-2 \% v/v) has become been used for the extraction of arsenic species in biological, plant materials and vegetable crops (Foster et al., 2007; Maher et al., 2013; Zhu et al., 2008). This approach was evaluated (procedure 3) and gave satisfactory results in terms of both the extraction efficiency and mass balance for the extracted arsenic species in NIES (101\%) and GBW10015 (106\%). The mass balance of detected arsenic species in both NIES and GBW10015 using $1 \% \mathrm{HNO}_{3}$ were in good agreement with the total arsenic concentration in extracts a microwave assisted acid digestion (Table 6).

Procedure 3 using $1 \% \mathrm{HNO}_{3}$ was then applied to evaluate the arsenic species in the collected rice samples. The main arsenic species found in the rice samples were As ${ }^{\text {III }}$, As ${ }^{~}$, DMA and MMA. It is well-documented that low concentration of nitric acid breaks down the amylose 
and amylopectin starches in the rice extract solutions. The results are shown in Table 6, and show good extraction efficiency for total arsenic in rice samples with values ranging from 91 to $110 \%$. The presence of organic arsenic species (DMA and MMA) in rice samples may confirm the ability of rice plant to metabolize inorganic arsenic to its organic species or they take up form the environment such as soil or the irrigating water.

In total, the arsenic in 17 different rice samples of different origin from around the world was determined. The total arsenic concentrations ranged from 0.054 to $0.823 \mu \mathrm{g} \mathrm{g}^{-1}$. For rice samples grown locally in the Kurdistan region of Iraq (KU1, KU2, KUH and IRQ see Table 2) the total arsenic concentrations ranged between 0.054 and $0.149 \mu \mathrm{g} \mathrm{g}^{-1}$. However, the total concentrations of arsenic in rice samples grown in Turkey (TUR1, TUR2, TUR3 TUR4 and TUR5) were higher and ranged from 0.145 to $0.823 \mu \mathrm{g} \mathrm{g}^{-1}$. The arsenic content of rice grown in Asian countries such as India, Pakistan, Mali and Thailand was in the range of 0.062 to $0.200 \mu \mathrm{g} \mathrm{kg}^{-1}$. In contrast, rice grown in the USA and Uruguay had arsenic levels 0.171 and $0.241 \mu \mathrm{g} \mathrm{g}^{-1}$, respectively. The lowest level found were in the Kurdistan region of Iraq (Akree north west of Arbeel) sample (KUA1) $0.054 \mu \mathrm{g} \mathrm{g}{ }^{-1}$, whilst rice from Turkey (TUR1) contained the highest arsenic level recorded in this study, $0.823 \mu \mathrm{g} \mathrm{g}^{-1}$ (Figure 3). Rice from India, Pakistan, Mali and Thailand fell into an intermediate category contained arsenic levels higher than rice grown in the Kurdistan region of Iraq and lower than of those rice samples from the USA, Uruguay and Turkey. The findings of this investigation are similar to those obtained in other studies and (Zavala \& Duxbury, 2008) reflect that the Asian rice contained lower arsenic levels than rice from the USA and Europe countries. . In this study rice samples KUA1, KUA2 and PAK contained arsenic concentration lower than the global normal range for arsenic in rice, and rice samples KUH, IRQ, THA1, THA2, THA3, IND, Mal, USA, TUR2 and TUR3 fell within the normal global range of arsenic in rice. Rice samples URU, TUR1 and TUR4 had arsenic levels higher than the global normal range of 
arsenic in rice. The THA 1 rice was distributed to all residence in Iraq and the Kurdistan region of Iraq during 2012 through a national food organisation distribution of Iraq. The full results are shown in Table 6.

The measurement of total inorganic arsenic present in foods is generally sufficient for risk assessment purpose. In all of the rice samples studied, the majority of arsenic species were inorganic arsenic species including both $\mathrm{As}{ }^{\mathrm{III}}$ and $\mathrm{As}^{\mathrm{V}}$ representing 51-100\% of total arsenic. These results confirm that rice is a bio-accumulative plant for the most toxic arsenic species. The highest level of arsenic was found in rice TUR1 and this high concentration may be due to the presence of mining adjacent to the rice paddy. This rice has arsenic level 4 times higher than the global normal range. 


\section{Conclusion}

The use of enzymatic extraction for the extraction of arsenic in staple foods was evaluated and compared with classical extraction procedures. Both real samples and certified reference materials (DORM-3, GBW10015 and NIES) were used in the study.

Quantitative and consistent extractions were achieved using trypsin for the extraction of arsenic species in fish with an extraction efficiency 90-104\%. Total arsenic in fish samples ranged between 3.53 and $98.8 \mu \mathrm{g} \mathrm{g}^{-1}$. Non-toxic AsB was the major species detected in all fish samples under investigation. The DMA was under the limit of detection in the majority of the samples. Except for the John dory sample, MMA was detected in all samples concentrations in the range 0.18 to $0.63 \mu \mathrm{g} \mathrm{g}^{-1}$. The John dory was below limit of detection. As ${ }^{\mathrm{V}}$ was found to be in the range of 0.19 to $1.09 \mu \mathrm{g} \mathrm{g}^{-1}$ except for the John dory sample which was below the limit of detection.

The use of $1 \% \mathrm{HNO}_{3}$ gave better extraction efficiencies than cellulase for the extraction of arsenic species in NIES rice flour and GBW10015 spinach. Satisfactory recoveries $101 \%$ and $106 \%$ were obtained for NIES and GBW10015, respectively. Arsenic in the residue of both CRMs was below limit of detection using $1 \% \mathrm{HNO}_{3}$. Moreover, using this procedure provided a better mass balance than extractions based on cellulase (procedure 2). The use of nitric acid, facilitated the extraction of arsenic species from the rice samples whilst maintaining the integrity of species. The inorganic arsenic (As ${ }^{\text {III }}$ and As ${ }^{\mathrm{V}}$ ) varied from 51$100 \%$ of total arsenic in the rice samples with $\mathrm{As}{ }^{\mathrm{V}}$ and $\mathrm{As}{ }^{\mathrm{III}}$ as the predominant species, while the remainder was mostly DMA. Within the limitations of this selective study, the highest level of inorganic arsenic was found in TUR1 from Turkey with $0.699 \mu \mathrm{g} \mathrm{g}^{-1}$ (As ${ }^{\text {III }}$ and As ${ }^{\mathrm{V}}$ ), whilst lowest total inorganic arsenic was found in a local rice from the Kurdistan region of Iraq with values of $0.043 \mu \mathrm{g} \mathrm{g}^{-1}$. 


\section{Acknowledgments}

For financial support the Ministry of Higher Education of Kurdistan region-Iraq is gratefully acknowledged. 


\section{References}

Branch, S., Ebdon, L., \& O'Neill, P. 1994. Determination of arsenic species in fish by directly coupled high-performance liquid chromatography-inductively coupled plasma mass spectrometry. J. Anal. At. Spectrom., 9(1), 33-37.

Brisbin, J. A., \& Caruso, J. A. 2002. Comparison of extraction procedures for the determination of arsenic and other elements in lobster tissue by inductively coupled plasma mass spectrometry. Analyst, 127(7), 921-929.

Caruso, J. A., Heitkemper, D. T., \& B'Hymer, C. 2001. An evaluation of extraction techniques for arsenic species fromfreeze-dried apple samples. Analyst, 126(2), 136-140.

Cuderman, P., \& Stibilj, V. (2009). How critical is the use of commercially available enzymes for selenium speciation? Analytical and bioanalytical chemistry, 393(3), 1007-1013.

Dufailly, V., Nicolas, M., Payot, J. R., \& Poitevin, E. (2011). Validation of a method for arsenic speciation in food by ion chromatography-inductively coupled plasma/mass spectrometry after ultrasonic-assisted enzymatic extraction. Journal of $A O A C$ International, 94(3), 947-958.

European Food Safety Authority (EFSA). 2009. Sceintific Opinion on Arsenic in Food. EFSA Journal, 7(10), 1351.

Foster, S., Maher, W., Krikowa, F., \& Apte, S. 2007. A microwave-assisted sequential extraction of water and dilute acid soluble arsenic species from marine plant and animal tissues. Talanta, 71(2), 537-549.

Francesconi, K. A. 2005. Current perspectives in arsenic environmental and biological research. Environmental Chemistry, 2(3), 141-145.

Francesconi, K. A. 2010. Arsenic species in seafood: Origin and human health implications. Pure and Applied Chemistry, 82(2), 373-381. 
Gallagher, P., Shoemaker, J., Brockhoff, C., \& Creed, J. 1999. Detection of arsenosugars from kelp extracts via IC-electrospray ionization-MS-MS and IC membrane hydride generation ICP-MS. Journal of Analytical Atomic Spectrometry, 14(12), 1829-1834. Gomez-Ariza, J., Sanchez-Rodas, D., Giraldez, I., \& Morales, E. 2000. Comparison of biota sample pretreatments for arsenicspeciation with coupled HPLC-HG-ICP-MS. Analyst, 125(3), 401-407.

Heitkemper, D. T., Vela, N. P., Stewart, K. R., \& Westphal, C. S. 2001. Determination of total and speciated arsenic in rice by ion chromatography and inductively coupled plasma mass spectrometry. Journal of Analytical Atomic Spectrometry, 16(4), 299-306.

Li, W., Wei, C., Zhang, C., Van Hulle, M., Cornelis, R., \& Zhang, X. 2003. A survey of arsenic species in chinese seafood. Food and Chemical Toxicology, 41(8), 11031110.

Maher, W., Foster, S., Krikowa, F., Donner, E., \& Lombi, E. 2013. Measurement of Inorganic Arsenic Species in Rice after Nitric Acid Extraction by HPLC-ICPMS: Verification Using XANES. Environmental Science \& Technology, 47(11), 5821-5827.

Mattusch, J., Cimpean, M., \& Wennrich, R. 2006. Enzyme-assisted extraction of arsenic species from plant material. International Journal of Environmental Analytical Chemistry, 86(9), 629-640.

Milstein, L. S., Essader, A., Murrell, C., Pellizzari, E. D., Fernando, R. A., Raymer, J. H., \& Akinbo, O. 2003. Sample Preparation, Extraction Efficiency, and Determination of Six Arsenic Species Present in Food Composites. Journal of Agricultural and Food Chemistry, 51(15), 4180-4184.

Nam, S.-H., Oh, H.-J., Min, H.-S., \& Lee, J.-H. 2010. A study on the extraction and quantitation of total arsenic and arsenic species in seafood by HPLC-ICP-MS. Microchemical Journal, 95(1), 20-24.

Nardi, E. P., Evangelista, F. S., Tormen, L., Saint'Pierre, T. D., Curtius, A. J., Souza, S. S. d., \& Barbosa Jr, F. 2009. The use of inductively coupled plasma mass spectrometry 
(ICP-MS) for the determination of toxic and essential elements in different types of food samples. Food Chemistry, 112(3), 727-732.

Pétursdóttir, Á. H., Gunnlaugsdóttir, H., Krupp, E. M., \& Feldmann, J. 2014. Inorganic arsenic in seafood: Does the extraction method matter? Food Chemistry, 150, 353359.

Rattanachongkiat, S., Millward, G. E., \& Foulkes, M. E. 2004. Determination of arsenic species in fish, crustacean and sediment samples from Thailand using high performance liquid chromatography (HPLC) coupled with inductively coupled plasma mass spectrometry (ICP-MS). Journal of Environmental Monitoring, 6(4), 254-261.

Reyes, L. H., Mar, J. L. G., Rahman, G. M. M., Seybert, B., Fahrenholz, T., \& Kingston, H. M. S. 2009. Simultaneous determination of arsenic and selenium species in fish tissues using microwave-assisted enzymatic extraction and ion chromatography-inductively coupled plasma mass spectrometry. Talanta, 78(3), 983-990.

Sadee, B., Foulkes, M., \& Hill, S. 2015. Coupled techniques for arsenic speciation in food and drinking water: a review. Journal of Analytical Atomic Spectrometry, 30(1), $102-$ 118.

Sanz, E., Muñoz-Olivas, R., \& Cámara, C. 2005. Evaluation of a focused sonication probe for arsenic speciation in environmental and biological samples. Journal of Chromatography A, 1097(1-2), 1-8.

Sun, G.-X., Williams, P. N., Zhu, Y.-G., Deacon, C., Carey, A.-M., Raab, A., Feldmann, J., \& Meharg, A. A. 2009. Survey of arsenic and its speciation in rice products such as breakfast cereals, rice crackers and Japanese rice condiments. Environment International, 35(3), 473-475.

Suñer, M. A., Devesa, V., Muñoz, O., López, F., Montoro, R., Arias, A. M., \& Blasco, J. 1999. Total and inorganic arsenic in the fauna of the Guadalquivir estuary: environmental and human health implications. Science of The Total Environment, 242(1-3), 261270. 
Urgast, D. S., Adams, G. C., Raab, A., \& Feldmann, J. (2010). Arsenic concentration and speciation of the marine hyperaccumulator whelk Buccinum undatum collected in coastal waters of Northern Britain. Journal of Environmental Monitoring, 12(5), 11261132.

Wahlen, R., McSheehy, S., Scriver, C., \& Mester, Z. 2004. Arsenic speciation in marine certified reference materials Part 2 . The quantification of water-soluble arsenic species by high-performance liquid chromatography-inductively coupled plasma mass spectrometry. Journal of Analytical Atomic Spectrometry, 19(7), 876-882.

Whaley-Martin, K., Koch, I., \& Reimer, K. 2013. Determination of arsenic species in edible periwinkles $(<\mathrm{i}>$ Littorina littorea $</ i>)$ by HPLC-ICPMS and XAS along a contamination gradient. Science of The Total Environment, 456, 148-153.

Zavala, Y. J., \& Duxbury, J. M. 2008. Arsenic in rice: I. Estimating normal levels of total arsenic in rice grain. Environmental Science \& Technology, 42(10), 3856-3860.

Zhu, Y.-G., Sun, G.-X., Lei, M., Teng, M., Liu, Y.-X., Chen, N.-C., Wang, L.-H., Carey, A., Deacon, C., \& Raab, A. 2008. High percentage inorganic arsenic content of mining impacted and nonimpacted Chinese rice. Environmental Science \& Technology, 42(13), 5008-5013. 


\section{List of Tables}

Table 1 ICP-MS and HPLC operating conditions used for the determination of total arsenic and arsenic speciation in sample digests and extracts.

\begin{tabular}{|c|c|c|}
\hline \multirow[t]{2}{*}{ ICP-MS } & \multicolumn{2}{|l|}{ X Series 2 (Thermo Scientific) } \\
\hline & Peristaltic pump speed $\mathrm{ml} / \mathrm{min}$ & 1.1 \\
\hline & Nebulizer type & V-groove \\
\hline & Spray chamber & Sturman-masters \\
\hline & Radio frequency power $(\mathrm{W})$ & 1350 \\
\hline \multirow[t]{3}{*}{ Gas flows/L $\min ^{-1}$} & Coolant & 13 \\
\hline & Auxiliary & 0.75 \\
\hline & Nebulizer & 1.0 \\
\hline $\mathrm{H}_{2}$ addition & $\begin{array}{l}\text { Gas flow }\left(\mathrm{ml} \cdot \mathrm{min}^{-1}\right) \\
7 \% \mathrm{H}_{2} \text { in } \mathrm{He}\end{array}$ & 3.6 \\
\hline \multirow{2}{*}{ Dwell time (ms) } & ICP-MS & 10 \\
\hline & HPLC-ICP-MS & 100 \\
\hline Column dimension & $250 \times 4.6 \mathrm{~mm}$ & \\
\hline $\begin{array}{ll}\text { Guard } & \text { column } \\
\text { dimension } & \end{array}$ & $50 \times 4.6 \mathrm{~mm}$ & \\
\hline Packing material & Hamilton resin PRP-X100, $10 \mu \mathrm{m}$ particle size & \\
\hline Eluent flow rate & $1.1-1.2 \mathrm{ml} \mathrm{min}^{-1}$ & \\
\hline Sample loop & $20 \mu \mathrm{l}$ & \\
\hline $\begin{array}{l}\text { Competitive } \\
\text { counter ion }\end{array}$ & $\begin{array}{l}\text { Sulphate }\left(\mathrm{Na}_{2} \mathrm{SO}_{4}\right) \\
\text { Ammonium dihydrogen phosphate }\left(\mathrm{NH}_{4} \mathrm{H}_{2} \mathrm{PO}_{4}\right)\end{array}$ & \\
\hline $\begin{array}{l}\text { Mobile phases } \\
\text { (isocratic elution) }\end{array}$ & $\begin{array}{l}\mathrm{A}=6.5 \mathrm{mmol} \mathrm{l}^{-1} \mathrm{Na}_{2} \mathrm{SO}_{4}, \mathrm{pH} 10.2,5 \% \mathrm{CH}_{3} \mathrm{OH} \\
\mathrm{B}=20 \mathrm{mmol} \mathrm{l}^{-1} \mathrm{NH}_{4} \mathrm{H}_{2} \mathrm{PO}_{4}, \mathrm{pH} 6.0,1 \% \mathrm{CH}_{3} \mathrm{OH}\end{array}$ & \\
\hline
\end{tabular}


Table 2 Origin of rice samples used in this study

\begin{tabular}{|l|c|c|c|}
\hline Types of rice & Country & Region & Label \\
\hline Short grain six months matured & Kurdistan-Iraq & Harir & KUH \\
\hline Short grain five months matured & Kurdistan-Iraq & Akree & KUA1 \\
\hline Short grain six months matured & Kurdistan-Iraq & Akree & KUA2 \\
\hline Hamber short grain rice & Iraq & - & IRQ \\
\hline Long grain rice & Thailand & - & THA1 \\
\hline Sainsbury's long grain rice & Uruguay & - & URU \\
\hline Sainsbury's Indian basmati rice six months matured & India & - & IND \\
\hline Tesco organic basmati rice & Pakistan & - & PAK \\
\hline Thai Glutinous rice & Thailand & - & THA2 \\
\hline Green dragon Thai rice & Thailand & - & THA3 \\
\hline Arrirang & USA & - & USA \\
\hline Long grain rice & Turkey & Beskiler & TUR1 \\
\hline Effsanel short grain rice & Turkey & Baldido & TUR2 \\
\hline Luts Persin short grain rice & Turkey & Mersin & TUR3 \\
\hline Beskiler long grain rice & Turkey & Gonen & TUR4 \\
\hline Duru long grain rice & Turkey & Balido & TUR5 \\
\hline Pure home Mali short grain rice & Mali & - & MAL \\
\hline
\end{tabular}

Table 3 Limit of detection for As ${ }^{\text {III }}$, As ${ }^{\mathrm{v}}$, MMA and DMA ( $\mu \mathrm{g} \mathrm{g}^{-1}$ dry weight), determined as the mean + 3SD of the background signal of method blank

\begin{tabular}{|l|c|c|c|c|c|}
\hline Method AsB & As III & DMA & MMA & As V \\
\hline Procedure 1 (Trypsin) & 0.015 & - & 0.022 & 0.034 & 0.027 \\
\hline Procedure 3 (cellulase & - & 0.008 & 0.019 & 0.025 & 0.008 \\
extraction) & & & & & \\
\hline Procedure 2 (1\% nitric acid) & - & 0.006 & 0.011 & 0.014 & 0.012 \\
\hline
\end{tabular}


Table 4 Certified reference material analyses for total arsenic; all values are given in $\mu \mathrm{g}$ $\mathrm{g}^{-1}$, mean \pm standard deviation $(\mathrm{n}=3)$

\begin{tabular}{|c|c|c|c|c|}
\hline CRM & Sample type & $\begin{array}{c}\text { Certified } \\
\text { value } \\
\text { value obtained }\end{array}$ & $\begin{array}{c}\text { Experimentaction } \\
\text { efficiency } \\
\%\end{array}$ \\
\hline DORM-3 & Fish protein & $6.88 \pm 0.3$ & $6.94 \pm 0.36$ & 101 \\
\hline $\begin{array}{c}\text { Rice flour unpolished- } \\
\text { high level Cd) }\end{array}$ & Rice & $0.150^{*}$ & $0.156 \pm 0.007$ & 104 \\
\hline GBW 10015 Spinach & Plant & $0.230 \pm 0.03$ & $0.249 \pm 0.008$ & 108 \\
\hline
\end{tabular}

*Indicative value 
Table 5 Results of analyses for arsenic concentration in the fish samples (dry weight); all values are given in $\mu \mathrm{g} \mathrm{g}^{-1}$ of $\mathrm{As}$, mean $\pm \mathrm{SD}(\mathrm{n}=3$ )

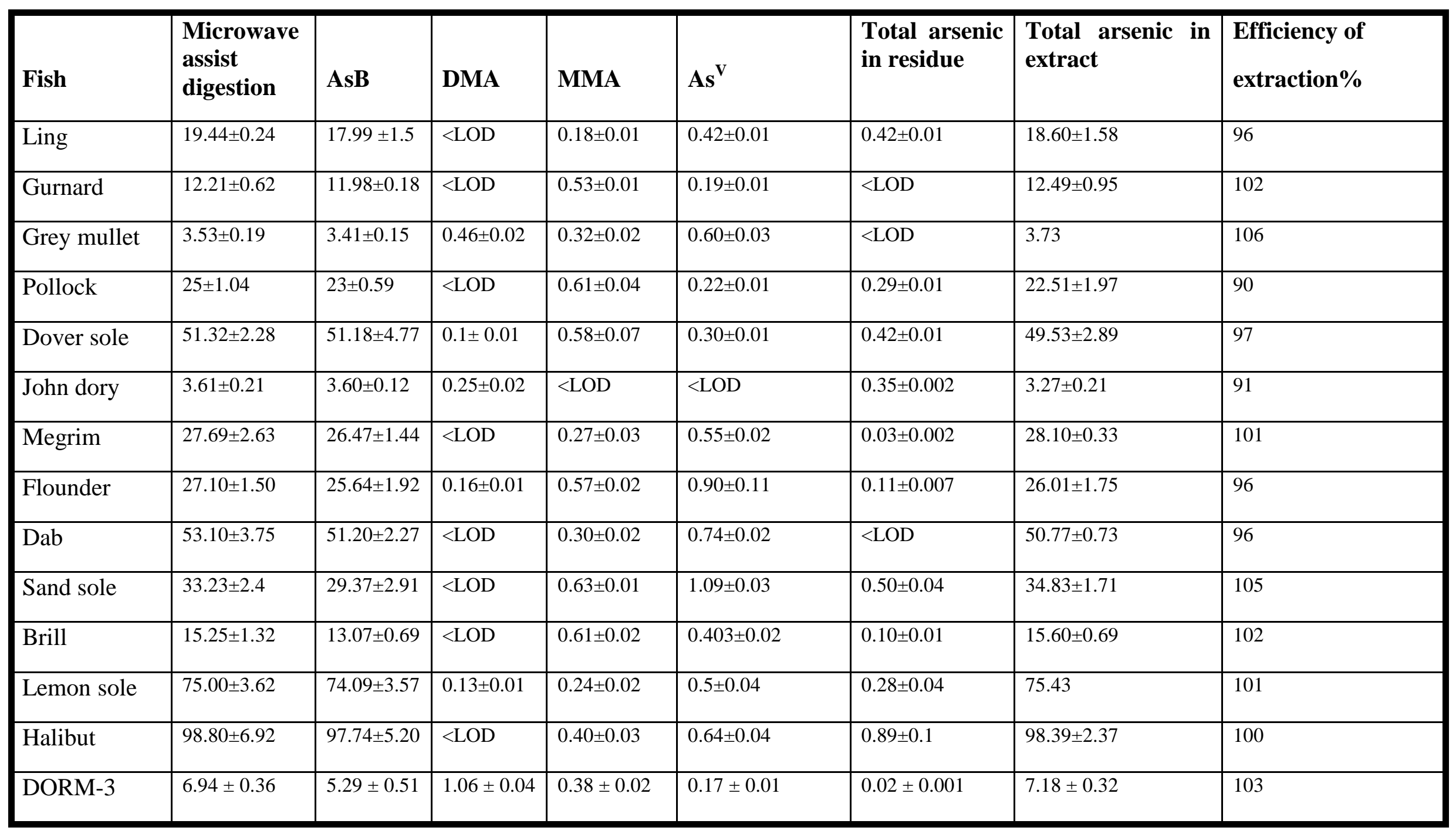


Table 6 Results of analysis for arsenic concentration in the rice samples (dry weight); all values are calculated in $\mu \mathrm{g} \mathrm{g}^{-1}$ of As, mean \pm standard deviation $(\mathrm{n}=3$ )

\begin{tabular}{|c|c|c|c|c|c|c|c|c|}
\hline Rice & $\begin{array}{c}\text { Microwave } \\
\text { assist digestion }\end{array}$ & As ${ }^{I I I}$ & DMA & MMA & As ${ }^{v}$ & $\begin{array}{l}\text { Total arsenic in } \\
\text { residue }\end{array}$ & $\begin{array}{c}\text { Total arsenic in } \\
\text { extract }\end{array}$ & $\begin{array}{c}\text { Extraction } \\
\text { Efficiency } \\
\%\end{array}$ \\
\hline KUA1 & $0.054 \pm 0.004$ & $0.043 \pm 0.001$ & $<\mathrm{LOD}$ & $<\mathrm{LOD}$ & $0.013 \pm 0.0004$ & $<\mathrm{LOD}$ & $0.056 \pm 0.004$ & 104 \\
\hline KUA2 & $0.069 \pm 0.003$ & $0.040 \pm 0.003$ & $0.023 \pm 0.001$ & $<\mathrm{LOD}$ & $<\mathrm{LOD}$ & $<\mathrm{LOD}$ & $0.063 \pm 0.006$ & 91 \\
\hline KUH & $0.161 \pm 0.0006$ & $0.041 \pm 0.001$ & $0.039 \pm 0.004$ & $<\mathrm{LOD}$ & $0.057 \pm 0.0022$ & $0.039 \pm 0.0017$ & $0.156 \pm 0.007$ & 97 \\
\hline IRQ & $0.149 \pm 0.008$ & $0.083 \pm 0.003$ & $\angle \mathrm{LOD}$ & $\angle \mathrm{LOD}$ & $0.079 \pm 0.0064$ & $<\mathrm{LOD}$ & $0.160 \pm 0.008$ & 107 \\
\hline THA1 & $0.121 \pm 0.0037$ & $0.046 \pm 0.003$ & $0.038 \pm 0.002$ & $<\mathrm{LOD}$ & $0.029 \pm 0.0024$ & $0.033 \pm 0.004$ & $0.133 \pm 0.013$ & 110 \\
\hline THA2 & $0.191 \pm 0.007$ & $0.029 \pm 0.001$ & $0.042 \pm 0.004$ & $0.030 \pm 0.001$ & $0.111 \pm 0.005$ & $<\mathrm{LOD}$ & $0.201 \pm 0.002$ & 105 \\
\hline THA3 & $0.191 \pm 0.0068$ & $0.030 \pm 0.002$ & $0.035 \pm 0.003$ & $<\mathrm{LOD}$ & $0.105 \pm 0.009$ & $0.010 \pm 0.002$ & $0.182 \pm 0.0049$ & 95 \\
\hline PAK & $0.062 \pm 0.0005$ & $0.028 \pm 0.0001$ & $0.020 \pm 0.0003$ & $<\mathrm{LOD}$ & $0.017 \pm 0.0009$ & $<\mathrm{LOD}$ & $0.066 \pm 0.006$ & 106 \\
\hline IND & $0.141 \pm 0.011$ & $0.035 \pm 0.0007$ & $0.033 \pm 0.0006$ & $<\mathrm{LOD}$ & $0.063 \pm 0.004$ & $<\mathrm{LOD}$ & $0.139 \pm 0.005$ & 99 \\
\hline MAL & $0.200 \pm 0.018$ & $0.047 \pm 0.0016$ & $0.045 \pm 0.002$ & $0.061 \pm 0.002$ & $0.059 \pm 0.005$ & $<\mathrm{LOD}$ & $0.214 \pm 0.003$ & 107 \\
\hline USA & $0.171 \pm 0.008$ & $0.063 \pm 0.0068$ & $0.020 \pm 0.0002$ & $\angle \mathrm{LOD}$ & $0.088 \pm 0.0008$ & $\angle \mathrm{LOD}$ & $0.169 \pm 0.0054$ & 99 \\
\hline URU & $0.241 \pm 0.0052$ & $0.036 \pm 0.0005$ & $0.071 \pm 0.002$ & $<\mathrm{LOD}$ & $0.122 \pm 0.01$ & $0.011 \pm 0.001$ & $0.246 \pm 0.0059$ & 102 \\
\hline TUR1 & $0.823 \pm 0.065$ & $0.138 \pm 0.0042$ & $0.126 \pm 0.011$ & $\angle \mathrm{LOD}$ & $0.561 \pm 0.028$ & $\angle \mathrm{LOD}$ & $0.828 \pm 0.035$ & 101 \\
\hline TUR2 & $0.190 \pm 0.0086$ & $0.040 \pm 0.001$ & $0.055 \pm 0.005$ & $0.046 \pm 0.002$ & $0.078 \pm 0.0015$ & $<\mathrm{LOD}$ & $0.207 \pm 0.017$ & 109 \\
\hline TUR3 & $0.145 \pm 0.0038$ & $0.044 \pm 0.004$ & $0.041 \pm 0.002$ & $\angle \mathrm{LOD}$ & $0.039 \pm 0.0028$ & $\angle \mathrm{LOD}$ & $0.135 \pm 0.011$ & 93 \\
\hline TUR4 & $0.218 \pm 0.0036$ & $0.060 \pm 0.001$ & $0.050 \pm 0.001$ & $0.037 \pm 0.001$ & $0.075 \pm 0.0023$ & $<\mathrm{LOD}$ & $0.235 \pm 0.018$ & 108 \\
\hline TUR5 & $0.249 \pm 0.018$ & $0.064 \pm 0.001$ & $0.059 \pm 0.002$ & $0.027 \pm 0.004$ & $0.060 \pm 0.0021$ & $<\mathrm{LOD}$ & $0.229 \pm 0.014$ & 92 \\
\hline NIES & $0.156 \pm 0.0073$ & $0.100 \pm 0.001$ & $0.027 \pm 0.0007$ & $<\mathrm{LOD}$ & $0.027 \pm 0.0018$ & $<\mathrm{LOD}$ & $0.157 \pm 0.019$ & 101 \\
\hline GBW10015 & $0.249 \pm 0.0086$ & $0.107 \pm 0.008$ & $<\mathrm{LOD}$ & $0.034 \pm 0.0025$ & $0.113 \pm 0.011$ & $<\mathrm{LOD}$ & $0.264 \pm 0.018$ & 106 \\
\hline NIES* & $0.156 \pm 0.0073$ & $0.097 \pm 0.005$ & $0.041 \pm 0.003$ & $<\mathrm{LOD}$ & $0.106 \pm 0.0035$ & $0.013 \pm 0.001$ & $0.258 \pm 0.013$ & 163 \\
\hline GBW10015* & $0.249 \pm 0.0086$ & $0.073 \pm 0.006$ & $0.034 \pm 0.006$ & $0.058 \pm 0.0005$ & $0.084 \pm 0.0042$ & $0.032 \pm 0.003$ & $0.297 \pm 0.013$ & 119 \\
\hline
\end{tabular}

*extraction using cellulase. KUA1:Short grain five months matured, KUA2: short grain six months matured, KUH: Short grain six months matured, , IRQ: Hamber short grain rice, THA1: Long grain rice, THA2: Thai Glutinous rice, THA3 Green dragon Thai rice, PAK Tesco organic basmati rice, IND Sainsbury's Indian basmati rice six months matured, MAL: Pure short grain rice home Mali, USA: Arrirang, URU Sainsbury's long grain rice, TUR1: Long grain rice, TUR2: Effsanel short grain rice, TUR3: Luts Persin short grain rice, TUR4: Beskiler long grain rice, TUR5:Duru long grain rice, NIES: unpolished rice flour, GBW10015: Spinach. 


\section{List of Figures}

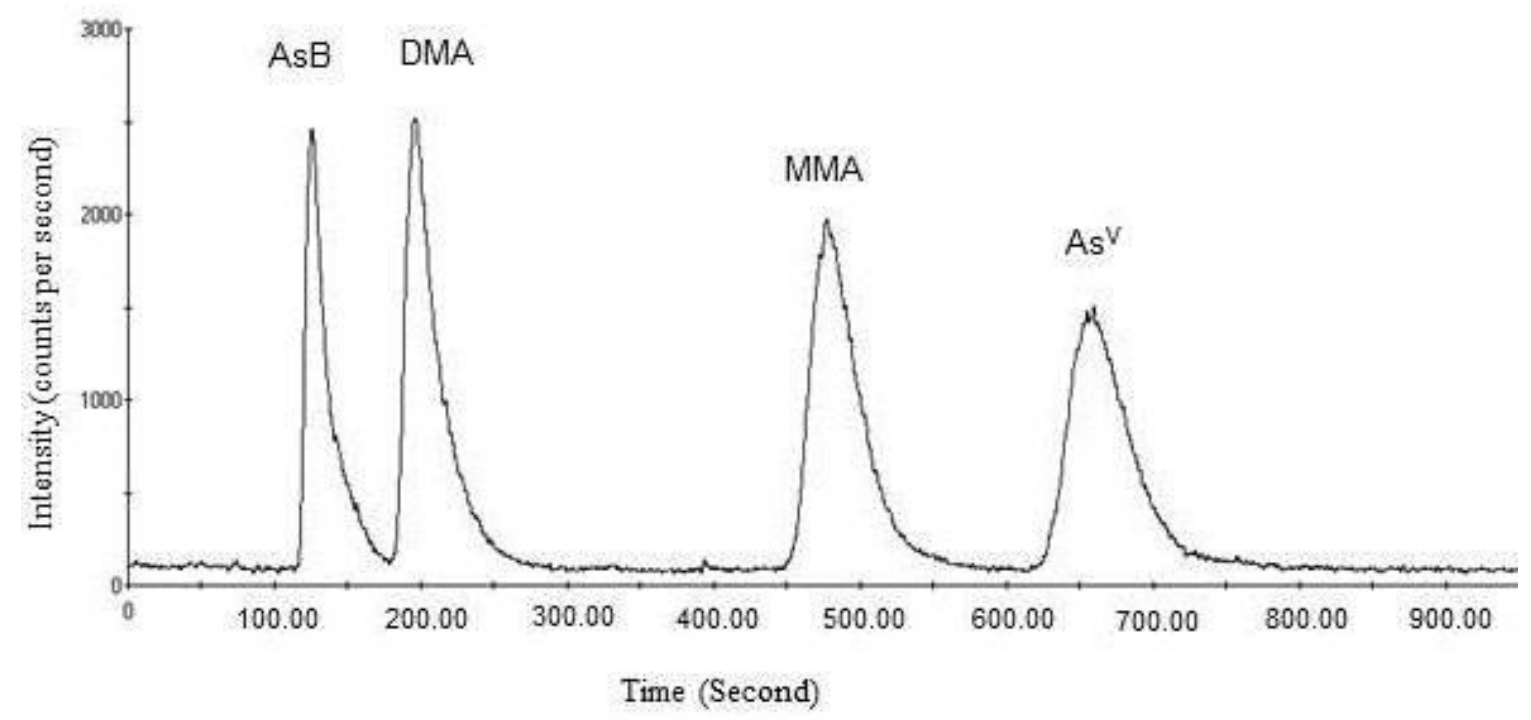

Figure 1 Chromatogram of four arsenic standards in aqueous solution. AsB, DMA and MMA and $\mathrm{As}^{\mathrm{V}} 100 \mu \mathrm{g} \mathrm{\textrm {I } ^ { - 1 }}$ As, employing a Hamilton PRP-X100 anion-exchange HPLC column using the conditions described in Table 1.

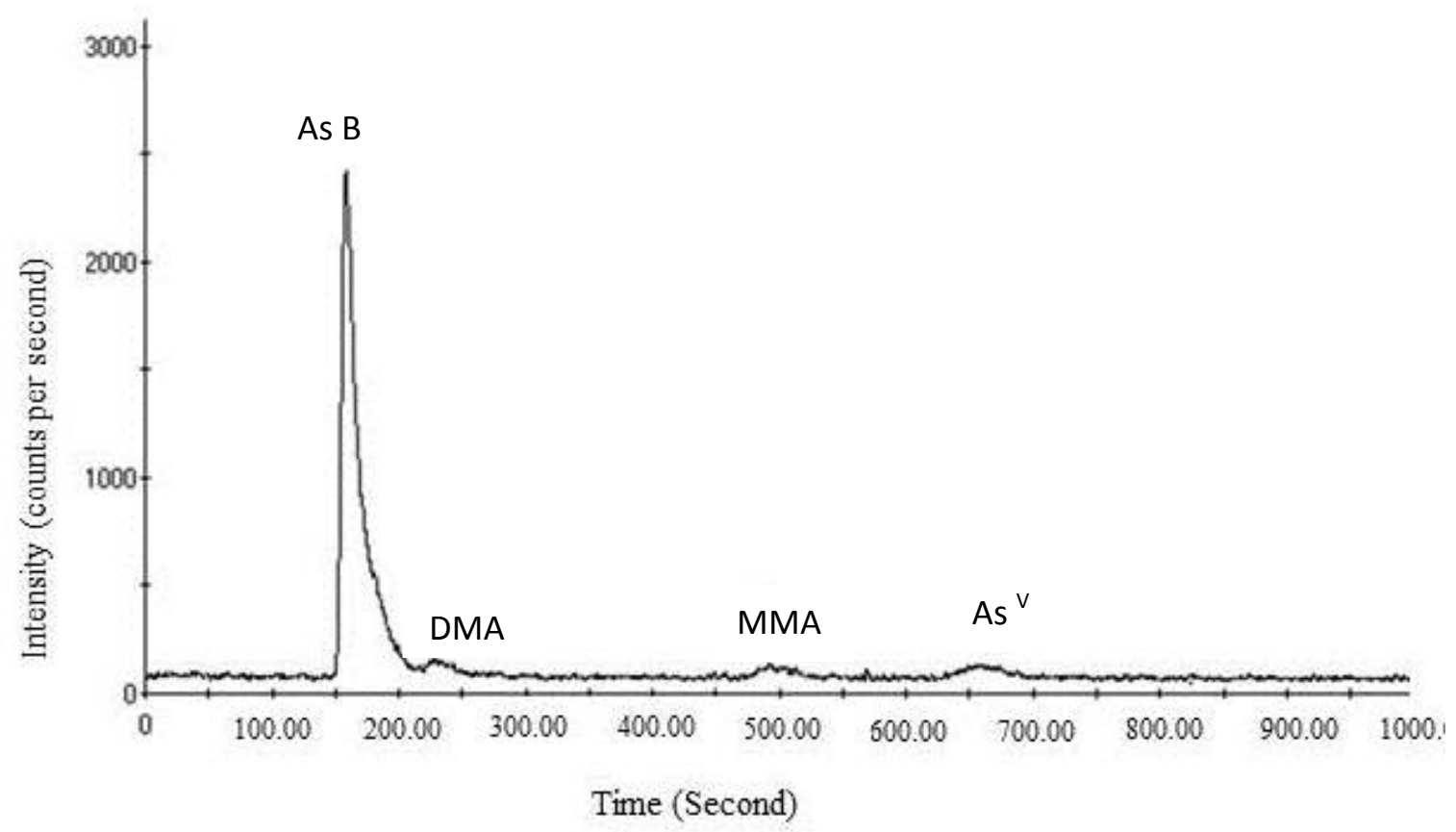

Figure 2 Chromatogram of sand sole using anionic-exchange HPLC-ICP-MS, using conditions described in Table 1. 


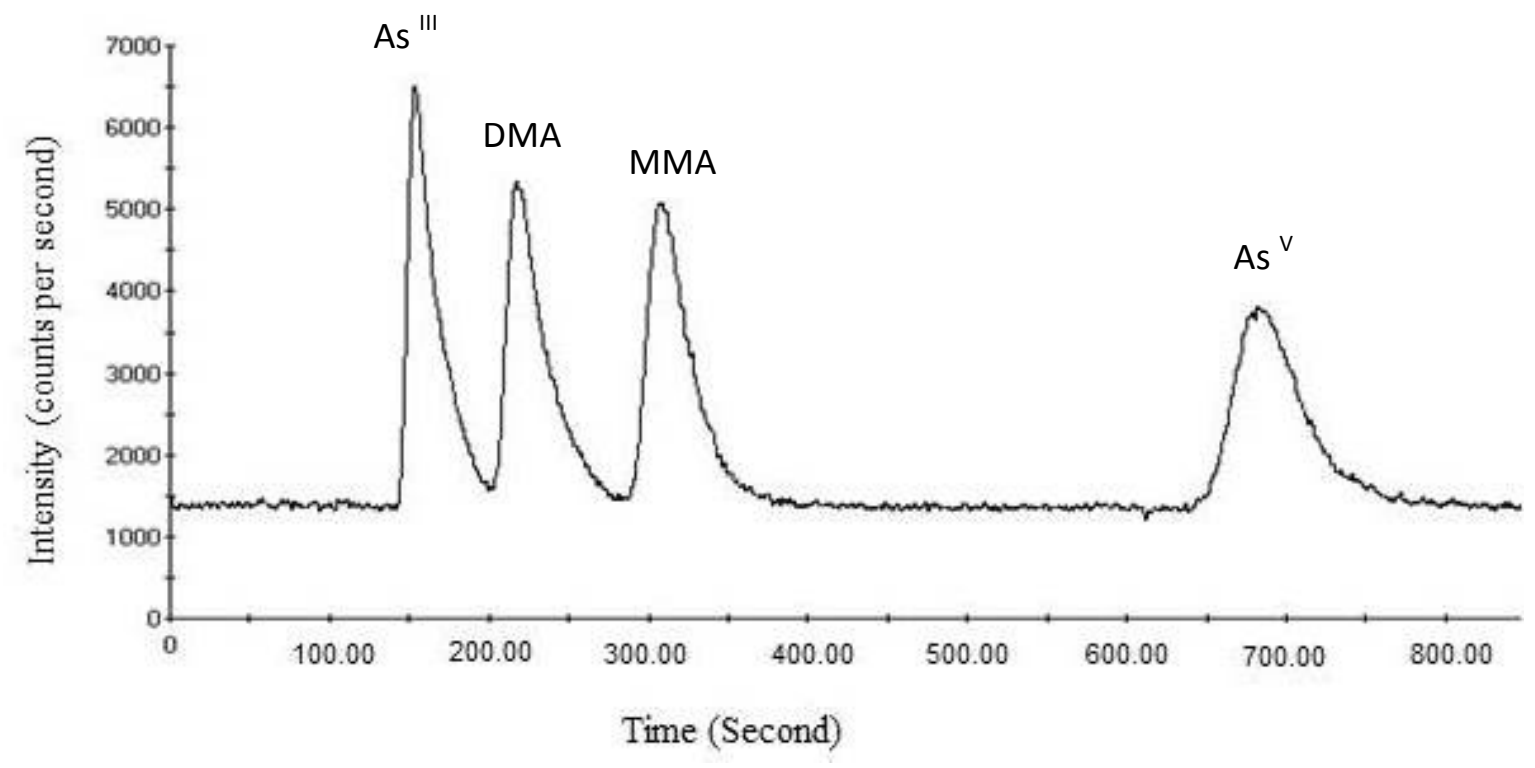

Figure 3 Chromatogram of four arsenic species standards in aqueous solution. As ${ }^{\text {III, }}$ DMA, MMA and As ${ }^{\mathrm{V}} 50 \mu \mathrm{g} \mathrm{I}^{-1}$ As, employing a Hmilton PRP-X100 anion-exchange HPLC column and $\mathrm{NH}_{4} \mathrm{H}_{2} \mathrm{PO}_{4}$ as mobile phase using conditions described in Table 1.

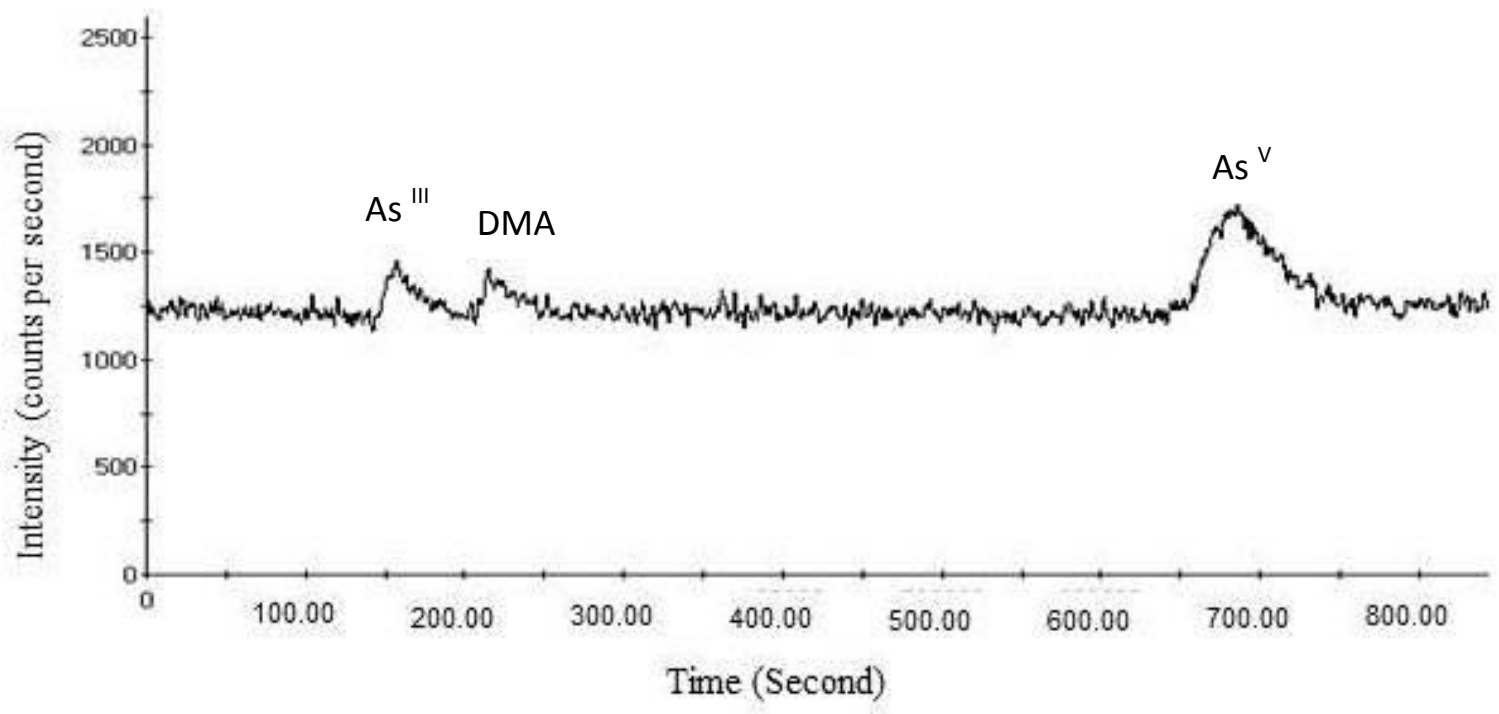

Figures 4 Chromatogram of TUR1 (Besklier (Tuerky)) rice using anionic-exchange HPLC-ICP-MS using conditions described Table 1. 